\title{
MONTE-CARLO SIMULATION OF ROAD TRANSPORT EMISSION
}

\section{Adam Torok ${ }^{1}$ \\ ${ }^{1}$ Budapest University of Technology and Economics, Department of Transport Technology and Economics, Hungary}

Received 24 July 2014; accepted 19 September 2014

\begin{abstract}
There are microscopic, mezoscopic and macroscopic models in road traffic analysis and forecasting. From microscopic models one can calculate the macroscopic data by aggregation. The following paper describes the disaggregation method of macroscopic state, which could lead to microscopic properties of traffic. In order to ensure the transform between macroscopic and microscopic states Monte-Carlo simulation was used. MS Excel macro environment was built to run Monte-Carlo simulation. With this method the macroscopic data can be disaggregated to macroscopic data and as a byproduct mezoscopic, regional data can be gained. These mezoscopic data can be used further on regional environmental or transport policy assessment.
\end{abstract}

Keywords: macroscopic data, Monte-Carlo simulation, microscopic data, environmental pollution, road transport.

\section{Introduction}

Transport represents a crucial sector of the economy. Carbon dioxide $\left(\mathrm{CO}_{2}\right)$ emissions from road transport increased by nearly $23 \%$ between 1990 and 2010, and without the economic crisis growth could have been even bigger. Transport is the only major sector in the EU where greenhouse gas emissions are still rising. Transport is responsible for around a quarter of EU greenhouse gas emissions making it the second biggest greenhouse gas emitting sector after energy. Road transport alone contributes about one-fifth of the EU's total emissions of $\mathrm{CO}_{2}$ (Fig. 1).
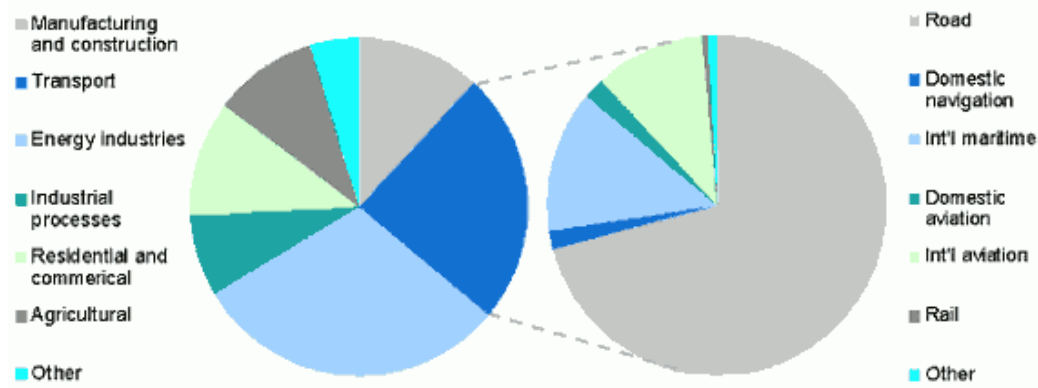

Fig. 1.

EU27 Greenhouse Gas Emissions by Sector and Mode of Transport, 2007

Source: http://ec.europa.eu/clima/policies/transport/index_en.htm

${ }^{1}$ Corresponding author: atorok@kgazd.bme.hu 
While emissions from other sectors are generally falling, those from transport have increased $36 \%$ since 1990. Basically aggregated, national, macro level data are available on road transport fuel consumption, vehicle fleet or mileage. $\mathrm{CO}_{2}$ emission and fuel consumption are influenced by these parameters. The existing research literatures on transport sector's $\mathrm{CO}_{2}$ emissions mainly distinguish between model categories of methodological perspectives. The first category is the bottom-up sector analysis where the microscopic data are available (Johansson, 1995; Bellasio et al., 2007; Junevičius et al., 2011; Praveen and Arasan, 2013; Hilmola, 2013; Domanovszky, 2014; Meszaros and Torok, 2014). This method is also useable to estimate emissions based on passenger travel behaviors in cities areas (He et al., 2013). The second method is the top-down analysis. Transport sector's $\mathrm{CO}_{2}$ emissions are generally decomposed into changes in fuel mix, modal shift, economic growth, population, changes in emission coefficients and transport energy intensity. This is a process of data disaggregation (Timilsina and Shrestha, 2009; Tian et al., 2014) where the studied factors responsible for the growth of transport sector's $\mathrm{CO}_{2}$ emissions, and the results showed that economic growth and transport energy intensity are the principal factors. Economic growth is one main factor behind $\mathrm{CO}_{2}$ emission increase in EU27 (Andreoni and Galmarini, 2012). The third method is system optimization. It has been widely used in forecasting energy and transport demand and $\mathrm{CO}_{2}$ emission (Azar et al., 2003; Luckow et al., 2010; Hassan et al., 2011; Ahanchian and Biona, 2014; Motasemi et al., 2014). The fourth method is econometric models. Using time series models, (Haldenbilen, 2006; Mraihi et al., 2013) investigated the role of the fossil fuel price in the demand of the transport sector. Lu et al. (2009) and Török and Török (2014) predicted the development trends of the number of motor vehicles, vehicular energy consumption and $\mathrm{CO}_{2}$ emission. Based on this no disaggregation method is reported yet which uses the macroscopic data and could lead to microscopic data of road vehicle's emission. In order to eliminate the gap that is found between the transformations of microscopic to macroscopic data Monte-Carlo simulation is used. The research hypothesis can be concluded as if the appropriate method can be found and used to disaggregate the macroscopic data then provided microscopic data are suitable for the assessment of regional transport and environmental policy incentives.

\section{Methods}

Monte-Carlo methods (or Monte-Carlo simulations) were computational algorithms that rely on repeated random sampling. Typically simulations were run many times in order to obtain the distribution of an unknown probabilistic parameter. MonteCarlo methods are often used in three distinct problem classes: optimization, numerical integration and generation of draws from a probability distribution. In this case probability distribution was simulated by Monte-Carlo method. Let us suppose that $(\bar{x})$ average mileage has the same value as the expected value of the $\zeta$ discrete vector variable (the vector size is dependent from the vehicle fleet, the elements of the vector are the mileage of vehicles as discrete random variables), $M\left(\zeta_{i}\right)$. In this case the approximation of $(\bar{x})$ as average mileage based on the Monte-Carlo method can be calculated by the large numbers of Bernoulli Act (Eq. (1)): 
$P\left(\bar{x}=\mathrm{M}\left(\zeta_{\mathrm{i}}\right)\right)=1$

The error magnitude of the simulation is Eq. (2):

$\delta \approx \frac{1}{\sqrt{N}}$

In order to significantly decrease the magnitude of error the number of simulations is needed to be significantly increased that would lead to significant increase in computational time. The development of personal computer made feasible to build up such simulation processes in MS Excel environment and made it viable to run the simulation within a reasonable time. For instance in case of South Hungary the simulation had been running Intel ${ }^{\circledR} \mathrm{Core}^{\mathrm{TM}}$ Duo CPU T2250 1.73 GHz 4 GB RAM laptop for 12 minutes. The aim of the simulation was to build up the vector variable for mileage and for fuel consumption in the investigated area to estimate the regional $\mathrm{CO}_{2}$ emission. The aggregated data are available at the Hungarian Statistical Office. Therefore the following top-down model was used (Eq. (3)):

$\sum_{i=1}^{n} \varepsilon_{i}=\sum_{i=1}^{n}\left(\Phi_{i} \cdot \frac{\rho_{i}}{100} \cdot \mathrm{E}_{i}\right)$

where:

$\varepsilon$ : yearly transport related $\mathrm{CO}_{2}$ emission of investigted area $\left[\mathrm{gCO}_{2} /\right.$ year $]$

$\Phi:$ mileage $[\mathrm{km} /$ year $]$ $\rho$ : fuel consumption [liter $/ 100 \mathrm{~km}$ ]

$\mathrm{E}$ : Emission factor of fuel $\left[\mathrm{gCO}_{2} /\right.$ liter fuel $]$ (Török, 2009; Zöldy, 2011; Bereczky, 2012) $\mathrm{n}$ : number of vehicles in the investigated area

From Eq. (3) the mileage $\left(\Phi_{i}\right)$ and the personal fuel consumption is not yet discovered $\left(\rho_{i}\right)$, only the aggregated, national and macroscopic data is known from Hungarian Statistical Office, therefore Monte-Carlo simulation was used (Fig. 2) to determine the variables. For this reason the mileage $\left(\Phi_{i}\right)$ and the personal fuel consumption $\left(\rho_{i}\right)$ was considered as vector variables. Monte-Carlo simulation were used to generate individual mileage and fuel consumption data for every vehicle. The mentioned two vector variables (for mileage and for fuel consumption) were used in four different cases (gasoline passenger car, diesel oil passenger car, diesel oil bus, and diesel oil heavy goods vehicle). Some simplifications were considered:

I It was assumed that the distribution of fuel consumption is a normal Gauss distribution with the expected value of 9.5 liter $/ 100 \mathrm{~km}$ in case of gasoline and 7.6 liter $/ 100 \mathrm{~km}$ of diesel oil (Kousoulidou et al., 2012; Samaras et al., 2012).

II The ratio of diesel vehicles $(\beta=0,25)$ is considered equal to the national average (Emőd and Török, 2010).

III It was assumed that the distribution of mileage is a normal Gauss distribution with the expected value $9000 \mathrm{~km}$ in case of gasoline driven vehicle and $11600 \mathrm{~km}$ of diesel oil driven vehicle (Paar et al., 2014). 


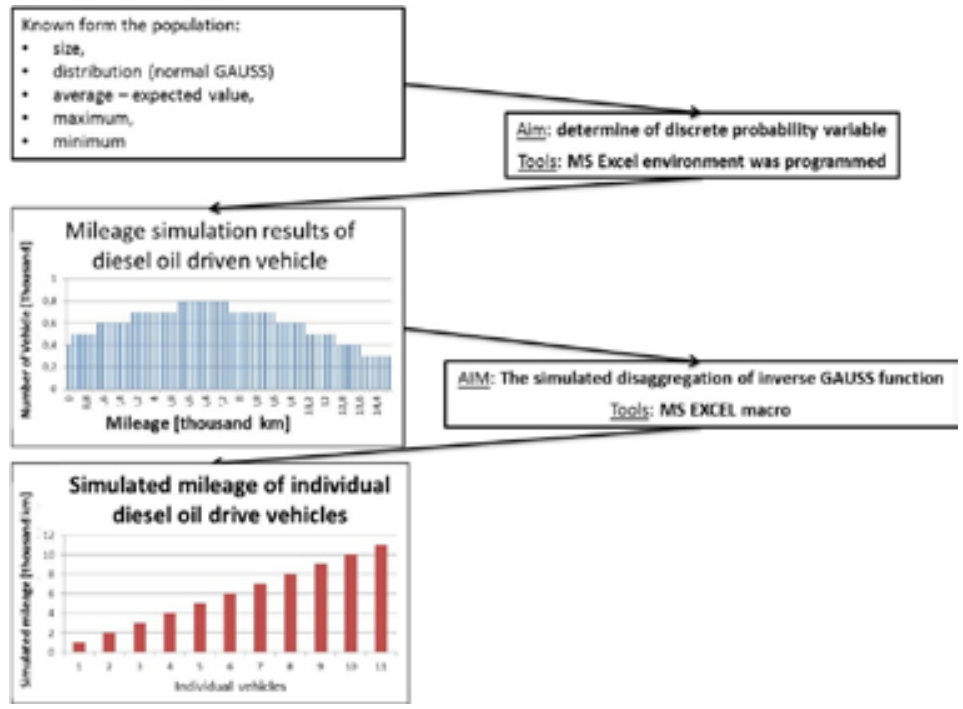

Fig. 2.

Simulation Method

\section{Results}

The area of investigation was the southern part of Hungary, where 24450 inhabitants were living in 2012 of which $50.78 \%$ were female and $49.22 \%$ were male (Figs. $3 a$ and $3 b$ ).

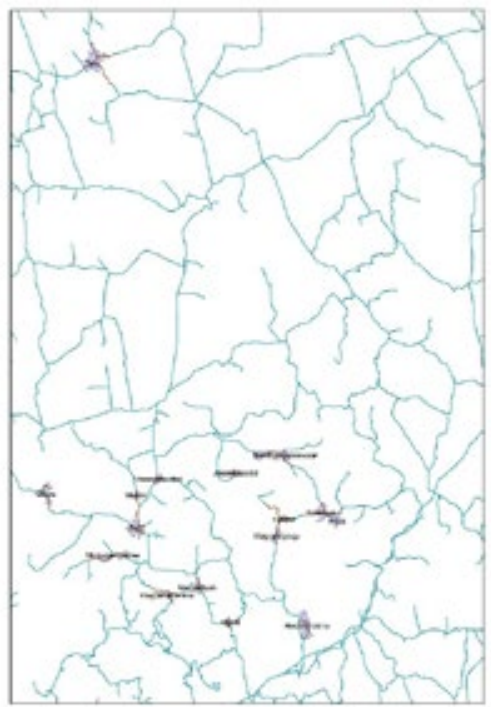

Fig. $3 a$.

Area of Investigation, Southern Part of Hungary

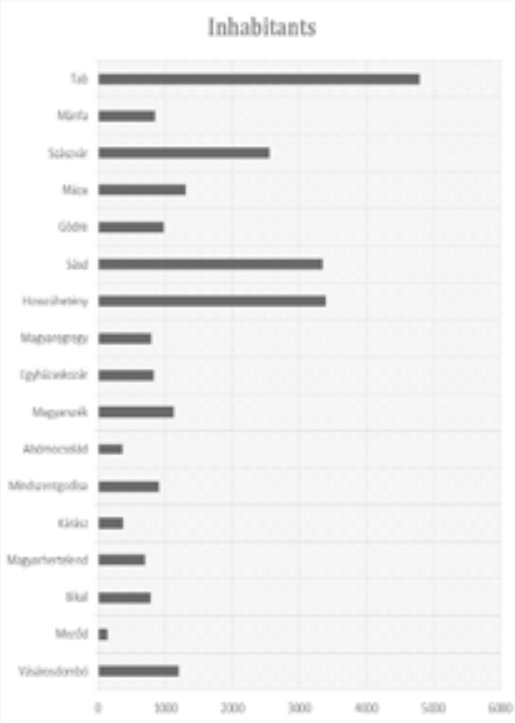

Fig. 3b.

Number of Inhabitants in the Investigated Area 
The average daily traffic of the region was 2170 PCU (Passenger Car Unit). 85\% of the traffic was passenger car, $10 \%$ was heavy goods vehicles, $3 \%$ was buses, $1 \%$ was motorcycle and $1 \%$ was agricultural vehicle. Based on the Monte-Carlo simulation described in methodology section, 17124 passenger cars with gasoline engine, 5708 passenger cars with diesel engine, 2703 heavy goods vehicles with diesel engine and 733 buses with diesel engine were simulated. As a result of simulation 11250232 liter of gasoline and 43817722 liter of diesel oil (Fig. 4) has been consumed by the road transport sector in the investigation area.

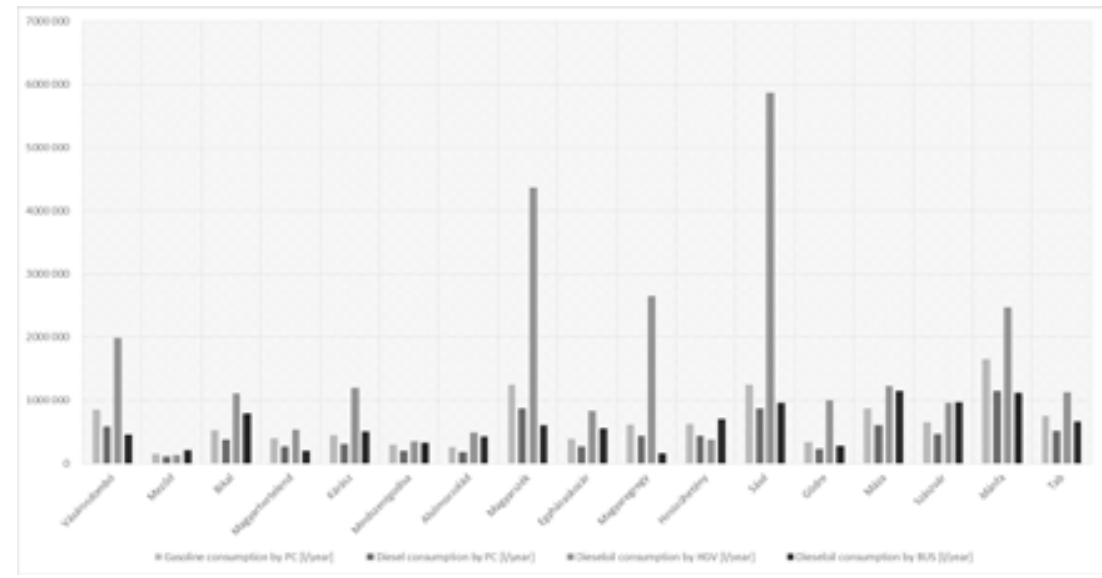

Fig. 4.

Calculated Fuel Consumption Based on the Monte-Carlo Simulation

Based on the simulation, an estimated $\mathrm{CO}_{2}$ emission in the area (Table 1).

\section{Table 1}

Estimated $\mathrm{CO}_{2}$ Emission by the Simulation

\begin{tabular}{|l|l|}
\hline Mode of transport & Estimated $\mathrm{CO}_{2}$ emission $[\mathrm{Gg} /$ year $]$ \\
\hline Passenger Cars & 45.7 \\
\hline Heavy Goods Vehicles & 57.4 \\
\hline Buses & 21 \\
\hline Total & 124.1 \\
\hline
\end{tabular}

Source: own estimation based on the Monte-Carlo simulation

\section{Analysis and Discussions}

A Monte-Carlo simulation has been made in order to disaggregate the macroscopic data. Due to the used simulation method individual characteristics such as mileage and fuel consumption has been modeled. Whit this method the local transport and environmental policy measures can be assessed. The results of the simulation tell us that the discrete vector variable can be modeled for individual mileage and fuel consumption for different vehicle classes (passenger cars, heavy goods vehicles and buses). With the help of the simulation the $\mathrm{CO}_{2}$ emission can be estimated. The 
punctuality of simulation can be increased but that would lead to significant increase in computational time. Currently only fossil fuels were considered in the simulation and in the $\mathrm{CO}_{2}$ emission estimation as well. Further on other type of fuels can be considered such as biofuel components, biogas, electric drives and hydrogen etc. The specified results can be extended, as the Monte-Carlo simulation can not only be used in top-down model categories.

\section{Conclusion}

Finally, the research hypothesis can be stated as the Monte-Carlo simulation is an appropriate method that can be used to disaggregate the macroscopic data in order to provided microscopic data which are suitable for the assessment of regional transport and environmental policy incentives. This tool can have role not only in top-down models, but can have significant role in other type of estimation as well. In the future the model will be extended with role of liquid biofuel components.

\section{Acknowledgements}

This paper was supported by the János Bolyai Research Scholarship of the Hungarian Academy of Sciences. Author is thankful for Mr. Gabor SZENDRO (iTEAM Ltd) for his help. The research was supported by Energy Club Ltd.

\section{References}

Ahanchian, M.; Biona, J.B.M. 2014. Energy demand, emissions forecasts and mitigation strategies modeled over a medium-range horizon: The case of the land transportation sector in Metro Manila, Energy Policy. DOI: http://dx.doi.org/10.1016/j.enpol.2013.11.026, 66: 615-629.
Andreoni, V.; Galmarini, S. 2012. European CO2 emission trends: A decomposition analysis for water and aviation transport sectors, Energy. DOI: http://dx.doi. org/10.1016/j.energy.2012.07.039, 45(1): 595-602.

Azar, C.; Lindgren, K.; Andersson, B.A. 2003. Global energy scenarios meeting stringent $\mathrm{CO} 2$ constraintscost-effective fuel choices in the transportation sector, Energy Policy. DOI: http://dx.doi.org/10.1016/S03014215(02)00139-8, 31(10): 961-976.

Bellasio, R.; Bianconi, R.; Corda, G.; Cucca, P. 2007. Emission inventory for the road transport sector in Sardinia (Italy), Atmospheric Environment. DOI: http:// dx.doi.org/10.1016/j.atmosenv.2006.09.017, 41(4): 677-691.

Bereczky, Á. 2012. Parameter analysis of NO emissions from spark ignition engines, Transport. DOI: http:// dx.doi.org/10.3846/16484142.2012.664563, 27(1): 34-39.

Domanovszky, H. 2014. Gas propulsion or e-mobility is the solution on the way of clean and carbon free road transportation?, Periodica Polytechnica Transportation Engineering. DOI: http://dx.doi.org/10.3311/PPtr.7254, 42(1): 63-72.

Emőd, I.; Török, Á. 2010. A hazai gépjárműállomány statisztikai vizsgálata különös tekintettel a károsanyag kibocsátásra (in Hungarian), Jövő Jármüve Jármüipari Innováció, 1: 16-21.

Haldenbilen, S. 2006. Fuel price determination in transportation sector using predicted energy and transport demand, Energy Policy. DOI: http://dx.doi. org/10.1016/j.enpol.2005.06.007, 34(17): 3078-3086.

Hassan, M.N.A.; Jaramillo, P.; Griffin, W.M. 2011. Life cycle GHG emissions from Malaysian oil palm bioenergy development: The impact on transportation sector's energy security, Energy Policy. DOI: http://dx.doi. org/10.1016/j.enpol.2011.02.030, 39(5): 2615-2625. 
He, D.; Liu, H.; He, K.; Meng, F.; Jiang, Y.; Wang, M.; Zhou, J.; Calthorpe, P.; Guo, J.; Yao, Z., Wang, Q. 2013. Energy use of, and $\mathrm{CO} 2$ emissions from China's urban passenger transportation sector - Carbon mitigation scenarios upon the transportation mode choices, Transportation Research Part A: Policy and Practice. DOI: http://dx.doi.org/10.1016/j.tra.2013.06.004, 53: 53-67.

Hilmola, O.-P. 2013. From Bubble to Sustainable Economy in the Baltic States, Transport and Telecommunication. DOI: http://dx.doi.org/10.2478/ ttj-2013-0021, 14(3): 237-249.

Johansson, B. 1995. Strategies for reducing emissions of air pollutants from the Swedish transportation sector, Transportation Research Part A: Policy and Practice. DOI: http://dx.doi.org/10.1016/0965-8564(95)00003-7, 29(5): 371-385.

Junevičius, R.; Bogdevičius, M.; Török, Á. 2011. Modelling Of Internal Combustion Engines' Emission Through The Use Of Traffic Flow Mathematical Models, Transport. DOI: http://dx.doi.org/10.3846/16484142. 2011.621978, 26(3): 271-278.

Kousoulidou, M.; Ntziachristos, L.; Fontaras, G.; Martini, G.; Dilara, P.; Samaras, Z. 2012. Impact of biodiesel application at various blending ratios on passenger cars of different fueling technologies, Fuel. DOI: http://dx.doi.org/10.1016/j.fuel.2012.03.038, 98: 88-94.

Lu, I.J.; Lewis, C.; Lin, S.J. 2009. The forecast of motor vehicle, energy demand and $\mathrm{CO} 2$ emission from Taiwan's road transportation sector, Energy Policy. DOI: http:// dx.doi.org/10.1016/j.enpol.2009.03.039, 37(8): 29522961.
Luckow, P.; Wise, M.A.; Dooley, J.J.; Kim, S.H. 2010. Large-scale utilization of biomass energy and carbon dioxide capture and storage in the transport and electricity sectors under stringent $\mathrm{CO} 2$ concentration limit scenarios, International Journal of Greenhouse Gas Control. DOI: http://dx.doi.org/10.1016/j. ijggc.2010.06.002, 4(5): 865-877.

Meszaros, F.; Torok, A. 2014. Theoretical investigation of emission and delay based intersection controlling and synchronising in Budapest, Periodica Polytechnica Transportation Engineering. DOI: http://dx.doi. org/10.3311/PPtr.7183, 42(1): 37-42.

Motasemi, F.; Afzal, M.T.; Salema, A.A.; Moghavvemi, M.; Shekarchian, M.; Zarifi, F.; Mohsin, R. 2014. Energy and energy utilization efficiencies and emission performance of Canadian transportation sector, Energy. DOI: http://dx.doi.org/10.1016/j.energy.2013.09.064, 64: 355-366.

Mraihi, R.; ben Abdallah, K.; Abid, M. 2013. Road transport-related energy consumption: Analysis of driving factors in Tunisia, Energy Policy. DOI: http:// dx.doi.org/10.1016/j.enpol.2013.07.007, 62: 247-253.

Paar, I.; Szoboszlay, M.; Telekesi, T. 2014. National Transport Strategy - Transport Energy Efficieny Enhancement Action Plan (in Hungarian: Nemzeti Közlekedési Stratégia - Közlekedési Energiahatékonyság Növelési Cselekvési Terv).

Praveen, P.S.; Arasan, V.T. 2013. Influence of traffic mix on pcu value of vehicles under heterogeneous traffic conditions, International Journal for Traffic and Transport Engineering. DOI: http://dx.doi.org/10.7708/ ijtte.2013.3(3).07, 3(3): 302-330.

\section{jitte 284}


Samaras, Z.; Ntziachristos, L.; Burzio, G.; Toffolo, S.; Tatschl, R.; Mertz, J.; Monzon, A. 2012. Development of a Methodology and Tool to Evaluate the Impact of ICT Measures on Road Transport Emissions, Procedia-Social and Behavioral Sciences. DOI: http://dx.doi.org/10.1016/j. sbspro.2012.06.1306, 48: 3418-3427.

Tian, Y.; Zhu, Q.; Lai, K.; Venus Lun, Y.H. 2014. Analysis of greenhouse gas emissions of freight transport sector in China, Journal of Transport Geography. DOI: http:// dx.doi.org/10.1016/j.jtrangeo.2014.05.003, 40: 43-52.

Timilsina, G.R.; Shrestha, A. 2009. Transport sector $\mathrm{CO} 2$ emissions growth in Asia: Underlying factors and policy options, Energy Policy. DOI: http://dx.doi. org/10.1016/j.enpol.2009.06.009, 37(11): 4523-4539.
Török, Á. 2009. Theoretical estimation of the environmental impact of biofuel mixtures, Transport. DOI: http://dx.doi.org/10.3846/16484142.2009.24.26-29, 24(1): 26-29.

Török, Á.; Török, Á. 2014. Macroeconomic analysis of road vehicles related environmental pollution in Hungary, Central European Journal of Engineering. DOI: http://dx.doi.org/10.2478/s13531-013-0147-0, 4(2): 186-191.

Zöldy, M. 2011. Ethanol-Biodiesel-Diesel Blends As A Diesel Extender Option On Compression Ignition Engines, Transport. DOI: http://dx.doi.org/10.3846/ 16484142.2011.623824, 26(3): 303-309. 